\title{
The Strategic Orientations And Determinants Of Wholly Owned Textiles Subsidiaries In The Mauritian Export Processing Zone - A Case Study Of The Textile And Wearing Apparel Sector
}

\author{
R V Sannassee, (E-mail: rvsan@uom.ac.mu), University of Mauritius, Mauritius
}

\begin{abstract}
This paper focuses on ascertaining the strategic orientations and determinants of wholly-owned subsidiaries in the Mauritian export-processing zone, with special emphasis on the textile and wearing apparel industry. The results show that costs minimisation, the ability to export to protected markets and the distinct possibility to evade barriers to entry imposed on their home nations were clear motivations underlying the establishment of operations by wholly-owned subsidiaries in the MEPZ. Furthermore, using regression analysis, the analysis shows that quality of infrastructure and cultural proximity were significant location determinants for $M E P Z$ whollyowned subsidiaries. Finally, using independent t-test, the results also highlight the greater prevalence attached by Asian firms to infrastructural provisions, cultural proximity and preferential access to developed markets in relation to their European counterparts.
\end{abstract}

\section{The Strategic Motivations of Wholly-Owned Subsidiaries in the MEPZ}

\subsection{Introduction.}

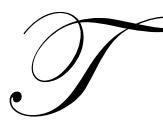

he motivations underpinning the strategic orientations of multinationals are very much dependent upon the nature of the investment and the industrialization strategies of the recipient counties of such investment. At the centre of the increase in global competition has been a lowering of trade barriers, which frequently has then been interdependent with a move to export-oriented development strategies in countries seeking to implement early phases in their industrialization. This nexus of strategic forces led to many MNEs systematically adopting (in the manner predicted for the third stage of Vernon's (1966) product cycle) the procedure of locating the production of technologically mature products in countries where the relevant standardized inputs were most cost-effectively available.

Export processing zones involve institutional arrangements that seek to go beyond the benefits of the generalized movement towards free trade and provide a setting for, interalia, particular facets of the MNEs' strategic needs. The ability to import into the zone intermediates (components and raw materials) at tariff levels (usually zero) below those of the non-zone parts of the same economy, provides encouragement for the location there of very specific activities of MNEs in the form of labour-intensive processing (or assembly) stages of their networked supply programmes (this very much reflects an efficiency-seeking behaviour).

The parallel stimulus of lower tariffs elsewhere on the re-exported goods is, of course, part of the general freer-trade context of this behaviour. A more specific advantage is the availability of open quotas for relevant goods in the preferential trade arrangements offered by those developed countries that are likely to be target markets for 
MNEs' products. Such preferential treatments (to certain developing countries) has nevertheless also encouraged the adoption of defensive strategies by those MNEs whose home countries face quota restrictions and high export tariffs imposed by the developed nations.

Proponents of the risk diversification hypothesis argue that MNEs possess certain non-financial advantages that enable them to manage the risks associated with an international diversified portfolio more effectively than their domestic counterparts. Rugman $(1979,1980)$ and Lessard (1982), for example have argued that, given that firms deemed it worthwhile to engage in FDI, the location of that investment would be a function of both the firm's perception of the uncertainties involved and the geographical distribution of its existing assets. Hence, over concentration of investment in one country would render the firm highly vulnerable to political and economic risks and the risks of expropriation (which may be the result of deterioration in the MNE/host government relation).

Furthermore, the interaction between foreign direct investment and technology is considered to be of paramount importance in the discussion of the foreign investment issue, both for the investing and host countries. The reason is to be found in the alleged benefits that technology confers on all parties.

A direct relationship can be discerned between the benefits derived by the MNEs (in terms of economies of scale and cost savings) and by the host country (employment creation and diffusion of technology) and the degree to which the technology transferred suits the local factor endowments. In the case of firms operating in export processing zones, which manufacture standardized and mature products, the transfer of technology which is highly labour intensive will undoubtedly reap greater benefits to both the transferor and the recipient of such technology.

Furthermore, the multinationals' country of origin may also have an effect upon the selection of, and the degree of adaptation to, the technology transferred. Several studies of multinationals from developing countries have indicated that the competitive assets of these firms are different from those of their counterparts from industrialized nations. These firms usually do not have the advantage of brand names or consumer loyalties. In most cases, they operate in industries using standard technologies (Wells, 1977, 1980, 1981; Lecraw, 1977, 1981).

However, studies on these developing countries' multinationals have indicated that their sources of competitive strength follow from a different set of conditions and factors. These firms have been able to acquire or develop labour-intensive, multipurpose technologies that need very low degree of adaptation and that can operate at a lower scale of production (Wells, 1978, 1980; Wells and Warren, 1979).

Along with, but distinct from, technological capability as an important advantage of multinationals, is their ability to create, acquire and organize human skills and competence (Dunning, 1993). The ability of the various subsidiaries' managers to coordinate their decentralized operations in various countries is very critical to the overall success of the group. And the possession of appropriate managerial skills will guarantee the furtherance of the benefits accruing to the various subsidiaries as well as to the group as a whole.

\subsection{Results:}

Table 1. depicts the mean responses of multinationals' directors (30) who were asked to rate on a scale of 1-5 ( 1 being not important to 5 being very important), the importance of various factors as strategic determinants for investing in the Mauritian export processing zone.

With an overall mean response of 3.07, and similar levels for Asian (3.20) and European (2.92) respondents, the suggestion that investments in the zone occurred 'as part of the group's global strategy to minimize costs' is at a level sufficient to confirm that dispersion of production facilities in order to pursue optimized efficiency in supply is a core imperative of textile and clothing firms with international competitive ambitions. This is in line with the third stage of Vernon's product life cycle which called for the relocation of production facilities of mature standardized products to low cost producing nations. 
Table 1. Evaluation of Foreign Investors' Strategic Motivations for Investing in the Mauritian EPZ.

\begin{tabular}{|l|c|c|c|}
\hline & \multicolumn{3}{|c|}{ Mean value $^{\mathbf{1}}$} \\
\hline Strategic Motivation & Asian & European & Total \\
\hline COSTMIN & 3.20 & 2.92 & 3.07 \\
\hline RISKDIV & 2.53 & 2.08 & 2.33 \\
\hline PRODTECH & 2.80 & 2.50 & 2.67 \\
\hline SUPSKILL & 2.60 & 2.25 & 2.44 \\
\hline TARRIFPROT & 3.87 & 2.08 & 3.07 \\
\hline PREFMARKETS & 4.53 & 3.25 & 3.96 \\
\hline
\end{tabular}

Strategic motivation:

COSTMIN - as part of the group's global strategy to minimise costs.

RISKDIV - to diversify risk.

PROD TECH - because of the possession of well-adapted technological production processes

SUPSKILL - because of superior managerial and technical skills

TARR IFPROT - because of the presence of high tariff barriers in key export markets vis a vis home country.

PREF MARKETS - because the country provides best preferential access to markets.

Increased international competition in the textile industry and the establishment of import quotas in the developed world have strongly affected how and where garments are manufactured. Firms from countries with binding quotas migrated to locations where quota restrictions are less stringent or absent (Roberts, 1992). These companies have found the export processing zones of developing countries an ideal place to establish their foreign manufacturing operations.

The results depicted from Table 1. clearly demonstrate that access of Mauritian production to major trade preferential agreements decisively attracted those firms, more specifically Asian ones, that needed to escape from their constrained home-country supply position. With an overall mean response of 3.96 , the provision of preferential access to developed markets was very much the main strategic motivation underlying the influx of wholly-owned subsidiaries into the Mauritian export processing zone. Nevertheless, such a consideration was deemed more crucial for Asian firms (mean of 4.53) than for their European counterparts (mean of 3.25). Such a difference can only serve to highlight the importance of residual trade distortions in the locational decisions of textiles and clothing companies.

Hence, not surprisingly, the location in the Mauritian zone 'because of the presence of high tariff barriers in key export markets vis a vis the home country' emerged as a crucial element for Asian investors (3.87). In contrast, this influence is the equal least strong for European respondents. It thus appears that the Asian companies involved, operate in segments of the market where home country exports remain affected by persisting trade restraints in their key markets, whilst the product lines of European firms seem to be much less affected in this way.

However, even though tariff protection was not seen as a major factor drawing production out of European firms' home countries, preferential access (along with the relatively high value for cost minimization) was a major factor pulling it into the Mauritian zone (highest mean of 3.25). So, even if the European enterprises operated in less protected, more fashion/quality oriented, segments of the market, elements of competitive edge provided by the export-processing zone were still notably relevant.

The major influence of tariff protection and preferential access to markets has two wider implications. Firstly, it suggests that whereas the importance of cost minimization is compatible with Kojima-style welfareenhancing trade creation, the crucial presence of these two factors indicates the influence of a trade diverting response to the residual patterns of protection in the textile and clothing industries. Secondly, it is shown that key reasons for operating out of the Mauritian zone relate to current institutional factors (protectionism) which are very likely to prove transitory, and which certainly do not provide, therefore, a basis for generating real roots in the local economy of a type that builds scope for further developmental commitment. 
In order to take advantage of EPZ operations, multinationals need to possess production techniques that can benefit from the available local input-cost structure and management and technical skills that can facilitate the specific mode of organization implied (i.e. holding an effective position in an intra-group supply network). As motivations for investment in the Mauritian zone, respondents were asked to evaluate 'because of the possession of well-adapted technological production processes' and 'because of superior managerial and technical skills'.

In this respect, the overall mean values of responses of these factors ( 2.67 for production techniques and 2.44 for technical skills) are high enough to demonstrate their relevance as important firm-level facilitating competences, but are clearly rather secondary to the three already reviewed in defining the context driving EPZ operations in textile and clothing enterprises.

With regards to the suitability of production technologies, the directors reasoned that though this was an important element in their decision making process, barriers to trade, preferential access to markets and cost minimization policies were deemed more critical. Furthermore, many directors argued that they had to adapt their production processes to suit the local factor endowments (16 firms) while in other instances, the product technologies, deemed too sophisticated, had to be kept unaltered to maintain product standards and specificities.

Finally, respondents were asked to evaluate 'to diversify risk' as a motivation for their EPZ operation. The results show that risk diversification emerged as the least strongly perceived motivation for wholly-owned subsidiaries. However, the directors reasoned that whilst political and economic stability were sine qua non conditions for minimizing the financial risks and risks of expropriation, other motivations such as the availability of export quotas to firms operating in the MEPZ and the opportunity offered by the Mauritian zone (especially to Asian firms) for avoiding the high barriers to entry imposed upon their home countries were more critical.

Furthermore, the relevance of such a factor would imply that inter alia the Mauritian zone helped provide stability to its MNEs' supply networks, through some degree of substitutability with activity of other parts. Nevertheless, the corollary of this is a vulnerability of the MEPZ operation itself, since its activity is also implicitly quickly replicable elsewhere which would underpin the argument of potential footloose behaviour and also suggest a strong bargaining power vis a vis the host country government.

\section{The Determinants of Multinational Subsidiaries in the MEPZ}

\subsection{Background}

It is undeniable that multinationals have been instrumental in the economic development of a number of less developed countries. Their contribution in curtailing unemployment (an acute problem in most developing countries) and in skill creation; in technology transfer and diffusion, which is an indispensable element for the development of indigenous industries; and in providing much needed foreign exchange, should not be underestimated.

In order to attract foreign direct investment, many developing countries have offered various investment incentives $^{1}$. However, the competition among developing countries seeking such investment had led to a proliferation of the types of incentives provided to the investors. These range from tax holidays and subsidisation of local wages, to free repatriation of profits by the foreign firms. But most studies undertaken to assess the importance of such incentives have concluded that they have very little impact on the location of foreign direct investment ${ }^{2}$.

\subsection{Methodology}

Initially, simple averages of specific determinants, that empirical evidence demonstrates as likely to be relevant in explaining foreign investment decisions, were calculated. Afterwards, these factors (set of testable

\footnotetext{
${ }^{1}$ Usually classified as financial and non-financial.

${ }^{2}$ For example, see Guisinger (1985); Lim (1983); and Rolfe and White (1992).
} 
propositions - 2.2.1.) were statistically tested (10\% Level of Significance), using regression analysis, to determine their impact on the intensity of initial investment of the foreign firms operating in the Mauritian zone.

\subsubsection{Set of Testable Propositions}

Proposition 1: There is a direct relationship between the significance attached to labour costs and the intensity of initial foreign direct investment in the host country.

Proposition 2: The greater the perceived political risk/instability in the local economy, the lower the intensity of foreign investment in Mauritius.

Proposition 3: The greater the tax incentives afforded to foreign investors, the greater the initial intensity of investment in the Mauritian export-processing zone.

Proposition 4: A more liberal system of regulations for zone firms is more conducive to attracting foreign investors. Hence, the more flexible the zone's regulations, the greater the initial intensity of investment in the zone.

Proposition 5: A higher and more sophisticated level of infrastructural support is more likely to attract a greater amount of foreign direct investment. Therefore, there is a direct relationship between the quality of infrastructure available in the economy and the volume of foreign investment.

Proposition 6: The greater the cultural proximity between the multinational's country of origin and the host nation, the greater the intensity of initial investment.

Proposition 7: The mode of entry is a significant determinant of the initial volume/intensity of investment. Fullyowned subsidiaries generally invest more substantially than foreign joint ventures.

\subsection{Data}

Two types of data were used in the statistical analysis. The first is hard data consisting of amounts of initial investment ${ }^{3}$. Such data was collected during the interview process. The second type consisted of scaled or coded evaluative judgements of individual respondents. This included evaluation on a five-point scale of the importance of labour costs, political stability, tax incentives, a more flexible regulatory framework, cultural proximity and a better quality of infrastructure.

Coded responses were also used in dummy variables representing the importance of export quotas. Toplevel executives of the companies or foreign managers who have had extensive familiarity with the companies' foreign operations compiled the evaluations in most cases.

\subsection{Results and Discussions of Findings}

\subsubsection{Mean Responses}

The strong and pervasive relevance of 'cheap and abundant labour' (LAB), with a mean response of 4.2, demonstrates the clear ability of the MEPZ to supply the key input in fulfilling one of the imperatives that globallycompeting enterprises expect to achieve from this mode of behaviour. A long-standing aspect of host-country support for EPZs has been a willingness to provide fiscal incentives to operators. This emerges as also a significant facet of attractive appeal of the MEPZ, with 'tax credits and holidays' (TAX) also recording an overall mean response of 4.2 .

\footnotetext{
${ }^{3}$ Given the initial investment by individual firms were made in different years, the values were adjusted using 1972 as the base year. The base year was chosen on the premise that it was the earliest year of establishment by any firm in the combined sample.
} 
Table 2. Evaluation of Reasons for Establishing Operations in the MEPZ

\begin{tabular}{|l|l|c|c|c|c|c|}
\hline & \multicolumn{6}{|c|}{ Reason for investing (mean value) } \\
\cline { 2 - 7 } & Lab & Cul.Pr. & Regul & Infra & \multicolumn{3}{c|}{ Stab } & Tax \\
\hline Fully-owned subsidiaries & & & & 4.9 & 4.5 & 4.4 \\
\hline Asian & 4.1 & 3.4 & 1.9 & 3.2 & 4.0 & 3.8 \\
\hline European & 4.3 & 1.8 & 2.8 & 3.6 & 4.1 & 4.2 \\
\hline Total & 4.2 & 2.5 & 2.3 & 3.6 \\
\hline
\end{tabular}

Where - Lab is Labour Costs

Cul. Pr. is Cultural Proximity

Regul is Flexible Regulations

Infra is Infrastructure Provisions

Stab is Political Stability

Tax is Tax Incentives

Furthermore, the need of zone-based operations to hold an internationally competitive position (often in wider networks of large companies) places pressure on them to not only meet low-cost targets but also provide high degrees of reliability in supply. Relative immunity from likely disruption is thus vital. On this basis 'political and economic stability' (STAB) emerged as the third crucial attractive factor of the MEPZ with a mean response of 4.1 .

Though less relevant than the three factors so far reported 'good infrastructure' (INFRA) is clearly a matter of some importance in the MEPZ, reporting a mean response of 3.6. Certainly infrastructure is another critical facet of the way that the manner of implementation of a particular zone can differentiate its appeal. The offering of a prebuilt factory space of high quality (and at artificially-low rent as part of the financial-incentive provisions) and effective and reliable international-communications infrastructure (seaport or airport) are thus influential elements of an EPZ package.

Finally respondents were asked to evaluate 'no stringent regulation pertaining to dismissal of labour forcelax labour laws and minimum wage legislation' (REGUL) as part of the appeal of the MEPZ. In fact this was reported as clearly the least relevant reason for investment, with a mean of 2.6. This factor relates to the frequent suggestion that some EPZs attract investors by providing them with a degree of discretion over their employment conditions that allows (in addition to low wages) the avoidance of social overheads (applied elsewhere in the local economy) and the bargaining limitations concomitant with easy dismissal.

Nevertheless, the much publicised and clearly pejorative connotations of this may have led to an unwillingness of respondents to recognise its relevance to their position. Alternatively it may be that a more supportive and generous attitude to employment conditions then contributes to the perceptions of political and economic stability as a major positive feature of operating in the MEPZ.

In a similar vein, for the fully-owned subsidiaries' sample, labour costs and tax concessions were very prominent (mean 4.2), while zone regulations (mean 2.3) and cultural proximity (mean 2.5) were insignificant motives for choosing the Mauritian zone as the most favoured location site.

\subsubsection{Regression Analysis and Independent t-tests Results}

A regression model (model 1) was also run to test the statistical significance of the above determinants in influencing the initial intensity of foreign direct investment.

\section{Model 1}

$\mathrm{INV}=\alpha+\beta_{1} \mathrm{LAB}+\beta_{2} \mathrm{POLI}+\beta_{3} \mathrm{TAX}+\beta_{4} \mathrm{FLEX}+\beta_{5} \mathrm{INFRAS}+\beta_{6} \mathrm{CULT}+\mathrm{u}$ 
Where - LAB is Labour Costs

POLI is Perceived Political Risk

TAX is Tax Incentives

FLEX is Flexible Regulations

INFRAS is Infrastructure Provisions

CULT is Cultural Proximity

Table 3. Results of the Regression Analysis of the Determinants of Fully-Owned Subsidiaries

\begin{tabular}{|l|c|c|}
\hline & $\boldsymbol{B}$ & Sig. \\
INDEPENDENT VARIABLES & $\boldsymbol{F . O}$ & F.O \\
\hline Constant & & 0.511 \\
\hline Quality of Infrastructure & 0.361 & 0.024 \\
\hline Labour Costs & -0.397 & 0.014 \\
\hline Perce. Political Risks & -0.112 & 0.451 \\
\hline Tax Incentives & 0.241 & 0.118 \\
\hline Cultural Proximity & 0.467 & 0.004 \\
\hline Stream. Zone Regulations & 0.224 & 0.151 \\
\hline
\end{tabular}

Dependent Variable: INVBASE72 $\quad N($ F.O $)=29^{i} \quad R^{2}(F O)=0.55$

The relevant statistical evidence presented in Table 3. above suggests that infrastructural provisions and cultural proximity were the only significant determinants significant for the fully-owned subsidiaries' sample while labour costs, perceived political risks, tax incentives and streamlined zone regulations were deemed unimportant.

The fully owned subsidiaries' sample was further sub-divided into two categories, namely: firms with parent companies in Europe, and firms with parent companies in Asia. Independent t-tests of the mean scores for the different variables were then conducted for the two sub-samples respectively. The results (Table 4.) show that infrastructural provisions and cultural proximity were systematically rated as being more important by Asian countries' directors.

Table 4. Independent t-test Comparing European and Asian Companies for the F.O Sample

\begin{tabular}{|l|c|c|c|}
\hline INDEPENDENT VARIABLES & $\begin{array}{c}\text { F.O ASIA } \\
\mathbf{N = 1 5}\end{array}$ & $\begin{array}{c}\text { F.O EUR. } \\
\text { N=12 }\end{array}$ & SIG. \\
\hline Quality of Infrastructure & 3.93 & 3.25 & 0.091 \\
\hline Labour Costs & 4.13 & 4.25 & 0.798 \\
\hline Perce. Political Risks & 4.47 & 4.00 & 0.323 \\
\hline Tax Incentives & 4.40 & 3.83 & 0.216 \\
\hline Cultural Proximity & 3.40 & 1.83 & 0.036 \\
\hline Stream. Zone Regulations & 1.93 & 2.83 & 0.101 \\
\hline
\end{tabular}

\subsubsection{Labour Costs}

There is the widely held notion that relatively low wages in developing countries is a primary attraction that lures foreign firms away from more advanced countries where labour costs are virtually prohibitive in comparison. Export-oriented firms do attach great importance to labour costs in their quest for higher level of competitiveness.

Using time series data, Wang and Swain $(1995,1997)$ found that labour costs played a very important role in foreign direct investment inflow in China. Boatman and Sun (1997) and Chen (1996) later confirmed such 
finding. Furthermore, how crucial a factor labour costs turns out to be, is dependent upon the industrialisation strategy of the host countries and the types of products being manufactured. Empirical studies that have examined the effect of labour costs on non-traditional exports in less developed countries, have demonstrated their importance ${ }^{4}$.

However, the significant negative relationships between the level of investment and the importance attached to labour costs for fully owned subsidiaries seems counter intuitive. But the information gathered from the interviews suggests that large multinationals rated labour costs as being unimportant as they only represent a fraction of their total costs of production. Also, these firms had invested massively in new technological processes such that the quality of the labour force rather than its costs is deemed more important and the mere fact that they are still operating in the zone ${ }^{5}$ despite substantial increases in labour costs testifies to that.

Furthermore, the data also reveals the presence of high value-added manufacturing operations within the zone. 16 multinationals, it may be argued, are engaged in the production of relatively high quality products. In this light, it is hardly surprising that labour cost, as a critical element, was indeed insignificant. These firms have always invested in the latest production technologies in their bid to remain internationally competitive and many of their directors have argued that the guarantee of an export market has been the crucial pulling factor.

The invariable response at each firm was that, besides being cheap, the quality of the labour force was also very important. Nevertheless, the recent downsize in the level of foreign direct investment has raised serious doubts as to the competitiveness of the zone. Increasingly, foreign as well as local firms are delocalising their operations to move to Madagascar where the cost of labour is relatively much lower. This reinforces the view that exportprocessing zones are self-defeating in that their very success does lead to a rise in the wage level in the zone, which may eventually lead to their downfall.

However, what the above implies is that the competitive advantage of the Mauritian zone is not and cannot be based solely on the availability of cheap labour. With the advent of the World Trade Organisation, firms in the zone need to move up market to be able to compete internationally. This largely explains the change in government policies vis-a-vis the zone and a number of measures aimed at improving the quality of products being manufactured therein $^{6}$ has been introduced. Hence, the importance of labour costs as a determinant factor for attracting foreign direct investment is bound to decrease in the future while on the other hand the quality ${ }^{7}$ and the productivity of the labour force should increase in significance.

\subsubsection{Cultural Proximity}

Not surprisingly, cultural proximity was a very significant factor in the locational decisions of fully-owned subsidiaries. The ethnic diversity of Mauritian businessmen and their fluency in both English and French has also been an added incentive in attracting investment partners from a variety of backgrounds (Hein, 1989). Furthermore, many firms, especially those originating from the Far East, hold very strong ethnic ties with the ever-increasing business influent Mauritian Chinese people.

The capacity of a host government to attract or discourage foreign direct investment is shaped not only by its policy measures and the country's factor endowments, but also that country's strategic location, history, language, religion and educational system that constitute its culture. Cultural affinity between countries is manifested by way of business, educational and linguistic exchanges.

\footnotetext{
${ }_{5}^{4}$ For example see Krueger (1987) and Riveros (1989).

${ }_{6}^{5}$ During the last decade, there has been a substantial amount of closures in the zone especially foreign firms.

${ }^{6}$ The Government has invested substantial amount of money in research and development to enable us to devise new means of production and also to help develop our own designs and labels. National quality competitions are being regularly organised and firms are increasing participating in international fairs via the Mauritius Export Development and Investment Authority (MEDIA). The Government has been encouraging forward linkages by allowing firms in the zone to form joint venture agreements with well-known supermarkets and chain stores in Europe.

${ }^{7}$ The firms stipulated that the workers will be required to adapt very quickly to the frequent change in the technology used given the product life cycle is much shorter nowadays.
} 
For example, Zhang and Yuk (1998), in a study of the determinants of manufacturing investment in China, found that the absence of language barriers was one of the most significant factors encouraging Hong Kong multinationals to invest in China. Such finding was consistent with some previous studies (Federation of Hong Kong, 1992; Zhang, 1994). Zhang (1994) pointed out that Guang Dong historical and ethnic connections with Overseas Chinese were very significant in attracting foreign investment.

The results (Table 3.) depict a significant positive relationship between cultural proximity and the initial investment intensity for the wholly-owned mode of entry. Directors of the multinational enterprises, more specifically the Asian ones, highlighted the importance of cultural factors such as strong ethnic ties and the ability to communicate in the same language. The results of the independent t-test, between the Asian country sample (mean of 3.40) and the European sample (mean of 1.83) for fully owned subsidiaries (Table 4.), clearly highlights the greater importance attached to cultural proximity by the directors of the Asian companies.

Finally, cultural proximity may prove very important in the context of regional integration because the undertaking of transactions and even the establishment of foreign subsidiaries (by the foreign firms currently in the Mauritian EPZ) in the region will very much depend on the cultural affinity between the nations within the trade block such as language similarity, historical background, legal and educational system and the presence of strong ethnic ties.

\subsubsection{Quality of Infrastructure}

The directors of the fully-owned subsidiaries viewed the provision of good infrastructure as significantly affecting the value of their initial investment. A necessary condition for the success of an export processing zone lies in the economic and policy environment that promotes private sector development and a local business community, and in many cases this requires the active intervention of the state to facilitate the provision of incentives, streamlined administration and management, appropriate site selection, infrastructure building and adequate investment promotion (Hooshang et al., 1995).

In this respect, the availability and provision of good infrastructural facilities is an important prerequisite for any host country willing to attract foreign direct investment. Root and Ahmed (1978), for example found that the greater the volume of a country's commerce, transport and communication, the more attractive a country is to foreign investors. Agodo's study (1978) also found that foreign firms placed great emphasis on the availability of primary infrastructure which reflected the deep concern for the adequacy and reliability of these facilities in African countries $^{8}$.

The availability of subsidised renting space, as well as discounted electricity and water rates have been very helpful to MEPZ firms. Furthermore, the provision of sound road networks and the relative proximity of zones to port of exports were added incentives for the foreign firms. In addition, the availability and the cost of air and sea transport was a critical issue for the Mauritian export-processing zone given its lack of proximity to its main markets and sources of supply.

However, one of the main problems facing the MEPZ was the high freight charges and the problem of port congestion (Forget, 1983). However, as the volumes of exports have increased, there has been a substantial reduction in air freight ${ }^{9}$ and the construction of deep water quays and a separate bulk sugar terminal has ended the problem of port congestion and reduced the turn around time for ships. The information gathered from the interviews confirmed the above.

On the other hand, directors were very critical of the frequent and substantial increases in electricity rates and telephone charges over recent years and they also criticised the government's policies on water management which they regard as being highly inadequate. There were also complaints about the poor state of some of the industrial zones, considered by some to be too old and even unhygienic. The directors were unanimous in their

\footnotetext{
${ }^{8}$ See also Zhang and Yuk (1998); Dunning (1993) and Broadman and Sun (1997).

${ }^{9}$ Lall et al. (1998) found that Mauritius has one of the cheapest freight costs in the region - even cheaper than most South East Asian countries.
} 
perception as to the inadequacy of these zones, even more so if and when the country moves to the next phase of its industrialisation process where multinational firms, of a totally different nature ${ }^{10}$, will be sought.

\subsubsection{Tax Incentives}

The non-significant association found between tax incentives and investment is instructive. Tax concessions are the most widely used by governments of developing countries to attract foreign direct investment. The pertinent statistical results in Table 3., however, show that tax incentives did not significantly affect the initial volume of investment for the wholly-owned subsidiaries' sample. The evidence gathered from the interviews supports this conclusion. The directors frequently mentioned during the interviews that tax concessions were usually regarded as a prerequisite condition for even considering investing in any export-processing zone. Furthermore, firms were reluctant to undertake projects which were solely dependent on tax rebates for achieving acceptable rates of return.

What the above entails is that though tax concessions are deemed very important by multinationals' directors (Mean: 4.2), they nevertheless do not significantly impact upon the initial intensities of investment by both modes of entries.

Tax incentives have not proved critical in affecting the initial volume of investment by subsidiaries in the Mauritian export-processing zone. One does not expect their importance to grow either. In any case, multinationals are known to use transfer pricing to minimise their global tax payments although such practice is almost impossible to prove.

\subsubsection{Perceived Political Risks}

The non-significant relationship between perceived political risk and the intensity of foreign investment seems counter-intuitive. Political stability of the host country and the continuity of policies is a critical factor in foreign investment decisions and is particularly so in the case of export processing zones, since many investment incentives are dependent on government legislation and its implementation.

Nevertheless, this finding could be explained by the fact that political stability is a sine qua none precondition for investing in any country, irrespective of the volume of investment. Furthermore, the overwhelming views of the directors were that political stability was a necessary but not sufficient condition and that there were other more important considerations impacting upon their locational decisions

However, the directors also voiced their concern as to the social unrest prevailing in the country over the last couple of years, which is symptomatic of deterioration in the economic performance of the country ${ }^{11}$. Such political and social unrest could have a negative impact on the ability of Mauritius to increase or even sustain the level of foreign direct investment in the zone. International investors are fickle characters and the slightest change in policy or in the political situation can lead to massive flight of capital to relocate elsewhere. The examples of Sri Lanka and Mexico, which witnessed sharp drops in their level of inward foreign direct investment following ethnic and civil unrest, will testify to that.

\subsubsection{Flexible Zone Regulations}

Flexible regulations within the Mauritian zone were not significant in foreign companies' volume of initial investment. These results confirm the view that export-processing zones are prima facie provided with the means which will allow investors to escape, to some extent, from the need to deal directly with the bureaucracy. Furthermore, potential investors are too aware of the high level of red tape in administrative procedures in developing countries such that flexible regulations within the zone do not rank high on their priority list.

\footnotetext{
${ }^{10}$ More capital intensive companies using highly sophisticated technology.

${ }^{11}$ There was even a riot in 1999, ensuing the death of a well-known local singer.
} 
Nevertheless, directors were adamant that the current regulations within the Mauritian zone need be reviewed and even changed drastically. First and foremost, there is too much delay in obtaining an operational license. The government has introduced the policy of one stop shop in a bid to reduce bureaucratic procedures. But, Lall et al. study (1998) on the competitiveness of the local zone shows that the time taken for the approval of operation permits is very lengthy in Mauritius. Directors were also highly critical of the labour laws prevailing in the zone, which many regard as being too favourable to employees ${ }^{12}$ and they rebutted the local customs procedures, which are too lengthy and cumbersome, and there were even mentions of corrupt practices within the civil service.

The evidence gathered from the interviews suggests that the current regulations prevailing in the zone are outdated and fundamental changes are required. Extensive bureaucratic requirements and consequent delays in government decision making are impinging negatively on potential investors. The costs being engendered by these bureaucracies should not be underestimated as they are often the reasons as to why, in certain countries, foreign investment has been negatively affected (Wall, 1976).

\section{Conclusion}

This paper pertains to analyzing the strategic orientations and motivations of multinational firms operating in the MEPZ. The results (table 1) clearly demonstrates that the possibility to export to protected markets, the ability to minimise costs and to evade barriers to entry facing their home countries were significant motivations for whollyowned subsidiaries (though more pronounced for Asian firms) to establish operations in the MEPZ.

Furthermore, there was also an attempt to analyse the determinants (attractiveness of location advantages) of wholly-owned firms operating in the MEPZ. Simple averages of pre-selected factors were calculated in the first instance. There was an overwhelming consensus among the directors as to the importance attached to factors such as labour costs, political stability and tax concessions and the insignificance of flexible zone regulations.

Furthermore, a regression model was run to analyse the impact of the different factors on the initial investment volume of foreign firms. The statistical evidence and information gathered from the interviews suggest that infrastructural provisions and cultural proximity were significant determinants of foreign manufacturing whollyowned subsidiaries in the Mauritian EPZ while streamlined zone regulations, tax incentives, perceived political stability and labour costs were not.

Independent $\mathrm{t}$-tests were also conducted to compare the importance of the different variables to foreign firms originating from Asia and Europe respectively. The results show that Asian fully-owned subsidiaries viewed quality of infrastructure and cultural proximity as being more crucial in their locational decisions than their European counterparts.

The Mauritian export-processing zone has been able to attract a significant amount of foreign investment during the early 1970's till the late 1980's. This was due to appropriate macroeconomic policies, an appropriate system of infrastructure, strong ethnic ties with Asian firms, relative low cost of labour and due to its preferential access to developed markets under the LOME Convention and the General System of Preferences.

However, the zone has witnessed a significant drop in the influx of foreign investment during the last few years. This is mainly due to an increase in the Mauritian labour costs, and increased global competition. And the information gathered from the interviews suggests that the current downward trend is very unlikely to change.

Furthermore, Mauritius can no longer rely on preferential trade agreements with developed markets to attract foreign direct investments and the comparative advantage based on the cost of labour has been eroded. Directors of foreign firms were also highly critical of the level of red tape present in the Mauritian administrative procedures and infrastructural facilities are becoming increasingly inadequate.

\footnotetext{
12 The Industrial Act of 1993 gave firms operating in the zone greater flexibility with regards to termination of employment in the zone. The current situation is very different indeed in that foreign firms are very often being sued for unfair dismissal.
} 
The future success of the zone as an attractive location for foreign direct investment will very much depend on the strategies adopted by the Mauritian government. Fortunately, the latter is fully aware of the current problems and the future challenges awaiting the export-processing zone. During the last few years, there has been a shift in government policies with greater emphasis now being placed on improving the quality of the labour force and encouraging firms to produce higher value added products. But, more measures aimed at reducing the level of red tape present in the local administrative systems and providing better quality of infrastructure, will have to be adopted by the government especially in its bid to attract more capital-intensive and technologically-advanced firms.

Nevertheless, whether the Mauritian export-processing zone will be able to attract further foreign direct investment into the textile sector is highly debatable. The general view is that the textile and wearing apparel industry is saturated and the only way the government will be able to increase the influx of future foreign investment into the zone is by diversifying the range of products being manufactured within the local zone and by targeting non textile manufacturing foreign direct investment.

As a last point, some of the practical and methodological limitations of the study need be highlighted. Firstly, the sample comprises of only existing/surviving firms. This may have led to bias in the results and a more appropriate sample should have included surviving as well as firms that have already closed down. For example, it would have been very interesting to test the significance of labour costs as a major location determinant for fullyowned subsidiaries that have closed down.

Secondly, the respondents were asked to make value judgments on decisions that were taken some years back and in some cases even 30 years ago. Finally, the independent variables (incentives, access to preference schemes) will vary little (if at all) objectively (i.e. its presence or value) between respondents. Therefore, it was the respondents' subjective need for/interpretation of this that varies between firms and which may have affected their investment decision.

\section{References}

1. Agodo, O. (1978). 'The Determinants of US Private Manufacturing Investments in Africa', Journal of International Business Studies, 9(3), winter, pp. 95-107.

2. Broadman, H. and Sun, X. (1997). 'The Distribution of Foreign Direct Investment in China', The World Economy, Vol. 20, No.3, pp. 339-62.

3. Chen, C. (1996). 'Regional Determinants of Foreign Direct Investment in Mainland China', Journal of Economic studies, 23(2), pp. 339-62.

4. Dunning, J.H. (1993). 'Multinational Enterprise and the Global Economy', Addison-Wesley, Wokingham.

5. Federation of Hong Kong Industries, (1992). 'Hong Kong Industrial Investment in the Pearl River Delta, 1991 Survey among Members of the Federation of Hong Kong Industries', Federation of Hong Kong Industries, Hong Kong.

6. Forget, P.A. (1983). 'Wishing a Future for the EPZ is not Enough', Les Pailles, Mauritius, Henry \& Cie.

7. Guisinger, S. (1985). 'A Comparative Study of Country Policies', in Stephen Guisinger, (ed.), Investment Incentives and performance Requirements. New York: Praeger.

8. Hein, P. (1989). 'Structural Transformation in an Island Country: The Mauritius Export processing Zone (1971-1988)', UNCTAD Review, Vol.1, No.2.

9. Hooshang, A. and Weiping, W. (1995). 'Export Processing Zones in Asia', Asian Survey, Vol. 35, No.9, pp. 828-50.

10. Krueger, A. (1987). 'The Relationships Between Trade, Employment and Development', Mimeo (Durham, NC: Duke University).

11. Lall, S. and Wignaraja, G. (1998). 'Mauritius: Dynamising Export Competitiveness', Economic Paper, No.33.

12. Lecraw, D.J. (1977). 'Direct Investment by Firms from Less Developed Countries', Oxford Economic Papers, 29, November.

13. Lecraw, D.J. (1981). 'The Internationalisation of Firms From LDCs: Evidence from the Asian Region', in Kumar and McLeod, (ed.). 
14. Lessard, D.R. (1982). 'Multinational Diversification and Direct Foreign Investment', in Eiteman, D.K. and Stonehill, A. (eds.). Multinational Business Finance. Reading MA. Addison-Wesley.

15. Lim, D. (1983). 'Fiscal Incentives and Direct Foreign Investment in Less Developed Countries', Journal of Development Studies, 19, 207-12.

16. Riveros, L.A. (1989). 'International Differences in Wage and Non-Wage Labour Costs', PRE Working Paper No. 188 (Washington, DC: The World Bank).

17. Roberts, M. (1992). 'Export Processing Zones in Jamaica and Mauritius: Evolution of an Export-Oriented Development Model', San Francisco Inquiries.

18. Root, F.R. and Ahmed, A.A. (1978). 'The Influence of Policy Instruments on Manufacturing Direct Foreign Investment in Developing Countries', Journal of International Business Studies, 9 (Winter), pp. 81-93.

19. Rugman, A.M. (1979). 'International Diversification and the Multinational Enterprise'. Lexington, MA: Lexington Books.

20. Rugman, A.M. (1980). 'Internalisation as a General Theory of Foreign Direct Investment, a Reappraisal of the Literature', Weltwirtschaftliches Archiv, Vol. 166, No.2, pp. 365-79.

21. Vernon, R. (1966). 'International Investment and International Trade in the Product Cycle', Quarterly Journal of Economics, Vol. 80, pp. 190-207.

22. Wall, D. (1976). 'Export processing Zones', Journal of World trade Law, Vol. 10, Sept/Oct, pp. 478-489.

23. Wang, Z. and Swain, N.J. (1995). 'The Determinants of Foreign Direct Investment in Transforming Economies: Empirical Evidence from Hungary and China', Weltwirtschaftliches Archiv, Vol. 131, No.2, pp. 359-82.

24. Wang, Z. and Swain, N.J. (1997). 'Determinants of Inflow of Foreign Direct investment in Hungary and china: Time-Series Approach', Journal of International Development, Vol. 9, No. 5, pp. 695-726.

25. Wells, L.T. (1977). 'The Internationalisation of Firms from the Developing Countries', in Agmon, T. and Kindleberger, C.P. (eds.), Multinationals from Small Countries. Cambridge, Mass: MIT Press.

26. Wells, L.T. (1978). Foreign Investment From Third World: The Experience of Chinese Firms from Hong Kong', Columbia Journal of World Business, spring, pp. 39-49.

27. Wells, L.T. (1980). 'Multinationals From Latin American and Asian Developing Countries: How They Differ?' Paper Submitted to the Harvard Graduate School of Business Administration, 10, November.

28. Wells, L.T. (1981). 'Foreign Investors from the Third World', in Kumar and McLeod. Lexington: D.C. Heath.

29. Wells, L.T. and Warren, V.A. (1979). 'Developing Country Investors and Indonesia', Bulletin of Indonesian Economic Studies, Vol. 15, March.

30. Zhang, L. (1994). 'Location-Specific Advantages and Manufacturing Direct Foreign investment in south China', World Development, Vol. 2, No.1, pp. 45-53.

31. Zhang, X. and Yuk, H.P. (1998). 'Determinants of Hong Kong Manufacturing in China: A survey', Marketing Intelligence and Planning, Vol. 16, No.4, pp. 260-267. 
Notes 
